Acta Protozool. (2018) 57: 107-122 www.ejournals.eu/Acta-Protozoologica doi:10.4467/16890027AP.18.010.8984 PROTOZOOLOGICA

\title{
Integrative Studies on the Morphology, Morphogenesis and Molecular Phylogeny of a Soil Ciliate, Parakahliella macrostoma (Foissner, 1982) Berger et al., 1985 (Ciliophora, Hypotrichia)
}

\author{
Yingzhi Ning,", Yongqiang Yang,,*, Tengteng Zhang,", Lingyun Chen ${ }^{1,}$ Khaled A. S. Al-Rasheid ${ }^{3}$, \\ Zhenzhen $\mathrm{Yi}^{4}$ \\ ${ }^{1}$ Laboratory of Microbiota, College of Life Science, Northwest Normal University, Lanzhou 730070, China; ${ }^{2}$ Institute of Evolution \\ and Marine Biodiversity, Ocean University of China, Qingdao 266003, China; ${ }^{3}$ Zoology Department, College of Science, King Saud \\ University, Riyadh 11451, Saudi Arabia; ${ }^{4}$ School of Life Science, South China Normal University, Guangzhou 510631, China
}

* These authors contributed equally to this work.

\begin{abstract}
The morphology and morphogenesis of two populations of the soil hypotrichous ciliate, Parakahliella macrostoma (Foissner, 1982) Berger et al. 1985, isolated from northwest China, were investigated based on specimens examined in vivo and stained with protargol. Our populations resemble the original one in terms of their live characters and cirral pattern. The main events during binary fission are as follows: (1) the parental adoral zone of membranelles is retained completely by the proter; (2) both in the proter and in the opisthe five frontal-ventral cirral anlagen are recognizable; (3) the marginal rows and dorsal kineties develop intrakinetally. In addition, the SSU rRNA gene was sequenced for the genus Parakahliella for the first time. Molecular phylogenetic analyses suggest that two populations of the genus Parakahliella cluster together and have a close relationship with species of Oxytrichidae.
\end{abstract}

Key words: Hypotrichs, Kahliellidae, ontogenesis, SSU rRNA, taxonomy

\section{INTRODUCTION}

The hypotrichous ciliates are a species-rich and morphologically diverse group that have been found in faunistic studies of different biotopes (Berger 1999, 2006, 2008, 2011; Chen et al. 2017a; Dong et al. 2016;

Address for correspondence: Lingyun Chen, Laboratory of Microbiota, College of Life Science, Northwest Normal University, Lanzhou 730070, China; E-mail: lychen@nwnu.edu.cn

Zhenzhen Yi, School of Life Science, South China Normal University, Guangzhou, China; E-mail: zyi@scnu.edu.cn
Hu and Kusuoka 2015; Li et al. 2017; Liu et al. 2017; Lu et al. 2017; Luo et al. 2017a, b; Lv et al. 2013; Pan et al. 2016; Shao et al. 2007, 2011, 2013, 2014, 2015; Wang et al. 2016, 2017a). Recently, phylogenetic analyses have led to a better understanding of systematic and evolutionary relationships among hypotrichs (Chen et al. 2017b; Gao et al. 2016, 2017; Huang et al. 2016; Li et al. 2016; Lv et al. 2015; Yan et al. 2018; Yi and Song, 2011).

The stichotrichid genus Parakahliella was established by Berger et al. (1985) and comprises three species: the type species, P. macrostoma (Foissner, 1982) 
Berger et al. 1985; P. haideri Berger and Foissner, 1989; and P. terricola (Buitkamp, 1977) Berger et al. 1985. Members of the genus can be clearly recognized by following characteristics: (1) undulating membranes long, curved, and optically intersect; (2) frontoventral cirral pattern relatively variable, basically composed of a buccal row, a parabuccal row, and two long frontoventral rows; (3) one or more right and left marginal rows; (4) transverse cirri lacking (Berger 2011). In so far, two populations of $P$. macrostoma have been characterized: the type population from the Lower Austrian lowland described by Foissner (1982), and an Alpine population studied by Berger et al. (1985). Several differences in the cirral patterns of the two described populations were noted, which implies that detailed descriptions of additional populations are needed in order to know the full range of morphological variability of this species (Foissner 1982; Berger et al. 1985).

In the present work, we describe two populations of Parakahliella macrostoma collected from Northwest China. In addition, we were able to describe some stages of their life cycle using protargol staining. The SSU rRNA gene sequence of $P$. macrostoma is also provided enabling the molecular phylogeny of Parakahliella to be investigated for the first time.

\section{MATERIAL AND METHODS}

Sampling, cultivation and isolation: Parakahliella macrostoma pop. 1 was collected from the upper layer of soil in the Walaka Wetland $\left(35^{\circ} 58^{\prime} \mathrm{N} ; 101^{\circ} 53^{\prime} \mathrm{E}\right)$, Gansu Province, China (Fig. 1), when the air temperature was $4.6^{\circ} \mathrm{C}$ and the $\mathrm{pH}$ measured 7.5. Five samples (about $500 \mathrm{~g}$ each) were taken in April 2011. Parakahliella macrostoma pop. 2 was collected from Gulang $\left(37^{\circ} 24^{\prime} \mathrm{N} ; 102^{\circ} 49^{\prime} \mathrm{E}\right)$, Gansu Province, China (Fig. 1), on 15 June 2016 (temperature $18.5^{\circ} \mathrm{C}$ ). The sample comprised $500 \mathrm{~g}$ of soil from the top $10 \mathrm{~cm}$ layer. All soil samples were air-dried for one month, sealed in large paper envelopes for ventilation, and investigated during 2017. The non-flooded Petri dish method (Foissner 1987; Foissner et al. 2002) was performed to stimulate ciliates to emerge from the soil sample. Cells were isolated and cultured at room temperature (about $20^{\circ} \mathrm{C}$ ) in Petri dishes containing distilled water with squeezed rice grains to enrich the availability of bacterial food.

Morphology, morphogenesis, and voucher material: Live cells were observed using bright field and differential interference contrast microscopy at 100-1,000× (Yan et al. 2016). Protargol staining (Wilbert 1975) was used to reveal the infraciliature and nuclear apparatus. The protargol was made according to Pan et al. (2013). Counts and measurements were performed with an ocular micrometer. Drawings were made with the help of a drawing device. In illustrations showing changes that occurred during morphogenesis, parental structures are depicted by contour, and new ones are shaded black. Terminology, numbering system for cirri, and systematics are according to Berger (2011) and Gao et al. (2016).

Twenty-four voucher slides (registration no. YYQ2016061502/A-X) have been deposited in the Laboratory of Microbiota, College of Life Science, Northwest Normal University, Lanzhou, China.

DNA extraction, PCR amplification, and sequencing: Cells of Parakahliella macrostoma pop. 1 and pop. 2 were isolated from ordinary cultures and washed to exclude potential contamination. The genomic DNA was extracted using DNeasy Blood \& Tissue Kit (Qiagen, Hilden, Germany), following the optimized manufacturer's protocol, but modified by using $1 / 4$ of the suggested volume for each solution. SSU rRNA gene primers were $82 \mathrm{~F}$ (5'-GAAACTGCGAATGGCTC-3') (Jerome et al. 1996) or 18s-F (5'-AACCTGGTTGATCCTGCCAGT-3') and 18s-R (5'-TGATCCTTCTGCAGGTTCACC TAC-3') (Medlin et al. 1988). The PCR amplifications were performed using Q5 ${ }^{\circledR}$ Hot Start High-Fidelity 2x Master Mix DNA Polymerase in the following protocol: $98^{\circ} \mathrm{C}$ for $30 \mathrm{~s}$, followed by 18 cycles of $98^{\circ} \mathrm{C}$ for $10 \mathrm{~s}, 69^{\circ} \mathrm{C}$ for $40 \mathrm{~s}$ with touchdown by $1^{\circ} \mathrm{C}$ for each cycle, $72^{\circ} \mathrm{C}$ for $90 \mathrm{~s} ; 18$ cycles of $98^{\circ} \mathrm{C}$ for $10 \mathrm{~s}, 51^{\circ} \mathrm{C}$ for $40 \mathrm{~s}, 72^{\circ} \mathrm{C}$ for $90 \mathrm{~s}$; and a final extension at $72^{\circ} \mathrm{C}$ for $4 \mathrm{~min}$. PCR products were purified by EasyPure Quick Gel Extraction Kit (Transgen Biotech, China), and then cloned using pClone007 Blunt Simple Vector Kit (Tsingke Biological Technology, China). One clone was picked randomly and cultured in LB Broth medium for 12 hours and sequenced bidirectionally in five reactions by the Tsingke Biological Technology Company (Beijing, China).

Phylogenetic analyses: The SSU rRNA gene sequences of two Parakahliella macrostoma populations were aligned with the sequences of 91 other ciliates downloaded from the GenBank database (see Fig. 8 for accession numbers) using the GUIDANCE2 algorithm (http://guidance.tau.ac.il/ver2/). Subsequently, unreliable columns below a confidence score of 0.335 were removed. Paradiophrys zhangi, Apodiophrys ovalis, Uronychia multicirrus and Diophrys scutum were chosen as outgroup taxa. The final alignment used for phylogenetic analyses included 1,754 sites. Maximum likelihood (ML) analysis with 1,000 bootstrap replicates was performed on the CIPRES Science Gateway with GTRGAMMA model (Miller et al. 2010) using RAxML-HPC2 on XSEDE 8.2.10 (Stamatakis 2014; Wang et al. 2017b). Bayesian inference (BI) analysis was carried out with MrBayes 3.2.6 on XSEDE (Ronquist and Huelsenbeck 2003) on the CIPRES Science Gateway using the model GTR + I + G selected by AIC in MrModeltest 2.2 (Nylander 2004). Markov chain Monte Carlo (MCMC) simulations were run for 6,000,000 generations with sampling every 100 generations and a burn-in of 6,000 trees. MEGA 5 (Tamura et al. 2011) was used to visualize the tree topologies (Zhao et al. 2017). The approximately unbiased (AU) test (Shimodaira 2002) was performed to test the monophyly of the focal group. The constrained ML tree was generated by limiting the monophyly of focal group with unspecific internal relationships within constrained taxa and the remaining taxa. The site-wise likelihood for the resulting constrained topology and the non-constrained ML topology were calculated by Paup 4.0 (Swofford 2002) and then calculated in CONSEL (Shimodaira and Hasegawa 2001). 


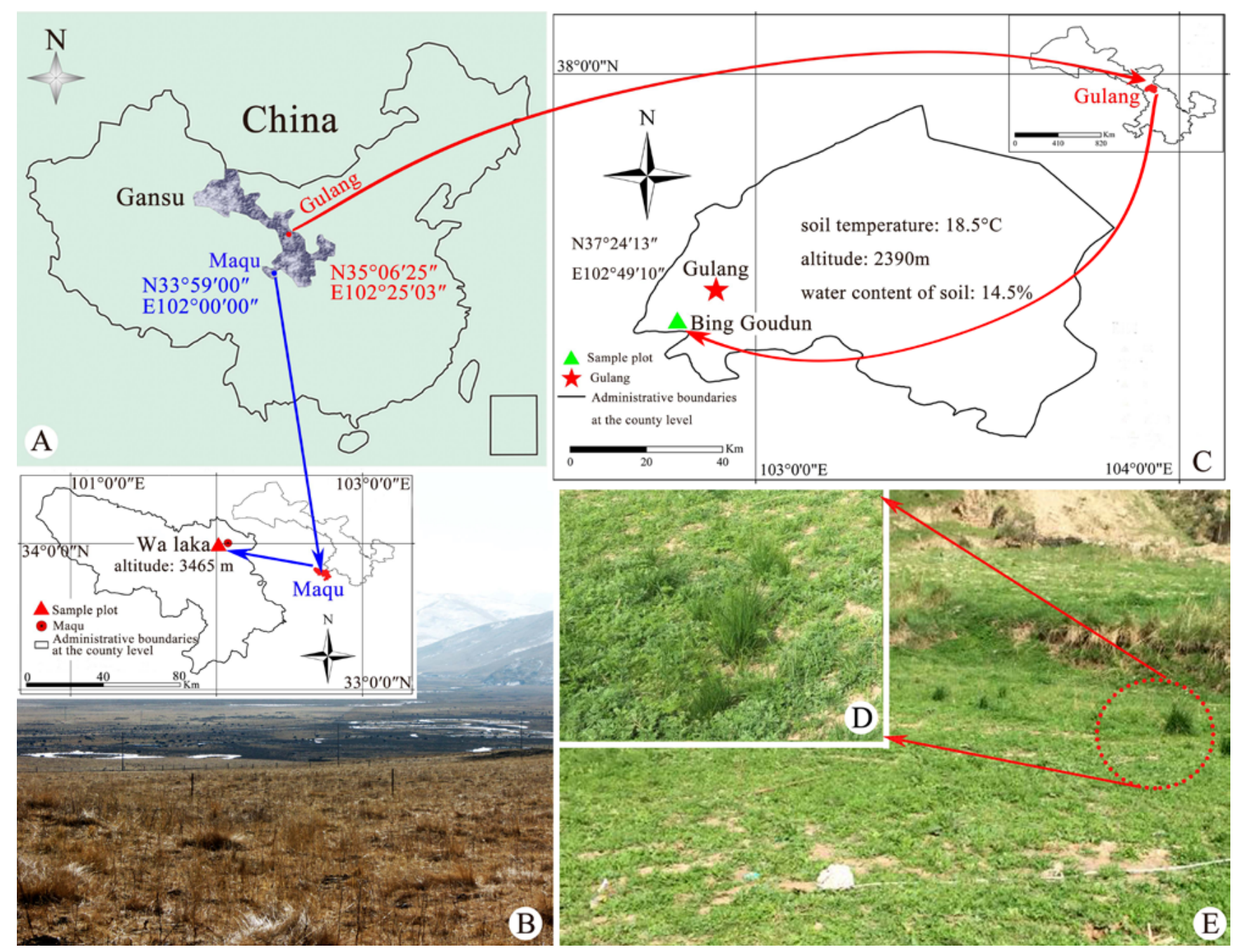

Fig. 1. Sample sites and surrounding areas. (A) Map showing the locations of Maqu and Gulang, Gansu Province. (B) Location where Parakahliella macrostoma pop.1 was collected and surrounding areas. (C-E) Location where Parakahliella macrostoma pop.2 was collected and surrounding areas.

\section{RESULTS}

\section{Morphology of Chinese populations of Parakahli-} ella macrostoma pop.1 and pop.2 (Figs 2-4; Table 1)

Body size in vivo about $160-235 \mu \mathrm{m} \times 60-100 \mu \mathrm{m}$ in pop. 1 and $135-180 \mu \mathrm{m} \times 55-85 \mu \mathrm{m}$ in pop. 2 ; length/ width about $2.6: 1$ in pop. 1 and $2.5: 1$ in pop. 2 in vivo $(\mathrm{n}=10), 2: 1$ on average in stained specimens. Pop.1 usually elongate oval to elliptical, the left and right margins almost parallel, anterior end rounded, posterior end slightly tapered; pop. 2 fusiform in outline with anterior end rounded, posterior end slightly narrow, right cell margin slightly convex, left side slightly to distinctly convex, usually widest in front of mid-body (Figs 2A,
D, 3A, B, 4A). Dorsoventrally flattened about 2:1 in vivo (Figs 3D, 4E). Pellicle semi-rigid. Cytoplasm hyaline and colorless, packed with numerous refringent globules and lipid droplets (3-6 $\mu \mathrm{m}$ across) in posterior portion, causing opaque and grayish appearance of this cell region at low magnification. Food vacuoles about $15 \mu \mathrm{m}$ in diameter in pop. 1 and $3-5 \mu \mathrm{m}$ in diameter in pop. 2 (Figs 3C, G, 4A, D). Cortical granules absent. Contractile vacuole slightly ahead of mid-body near left cell margin, contracting at intervals of about $10 \mathrm{~s}$, about $20 \mu \mathrm{m}$ (pop.1) and $14 \mu \mathrm{m}$ (pop.2) in diameter (Figs 3E, F, 4A, C). Macronuclear nodules, spherical to ellipsoid, about $20 \mu \mathrm{m} \times 10 \mu \mathrm{m}$ after protargol staining, numbering $8-10$ and $4-9$ in pop. 1 and pop. 2 respectively, 

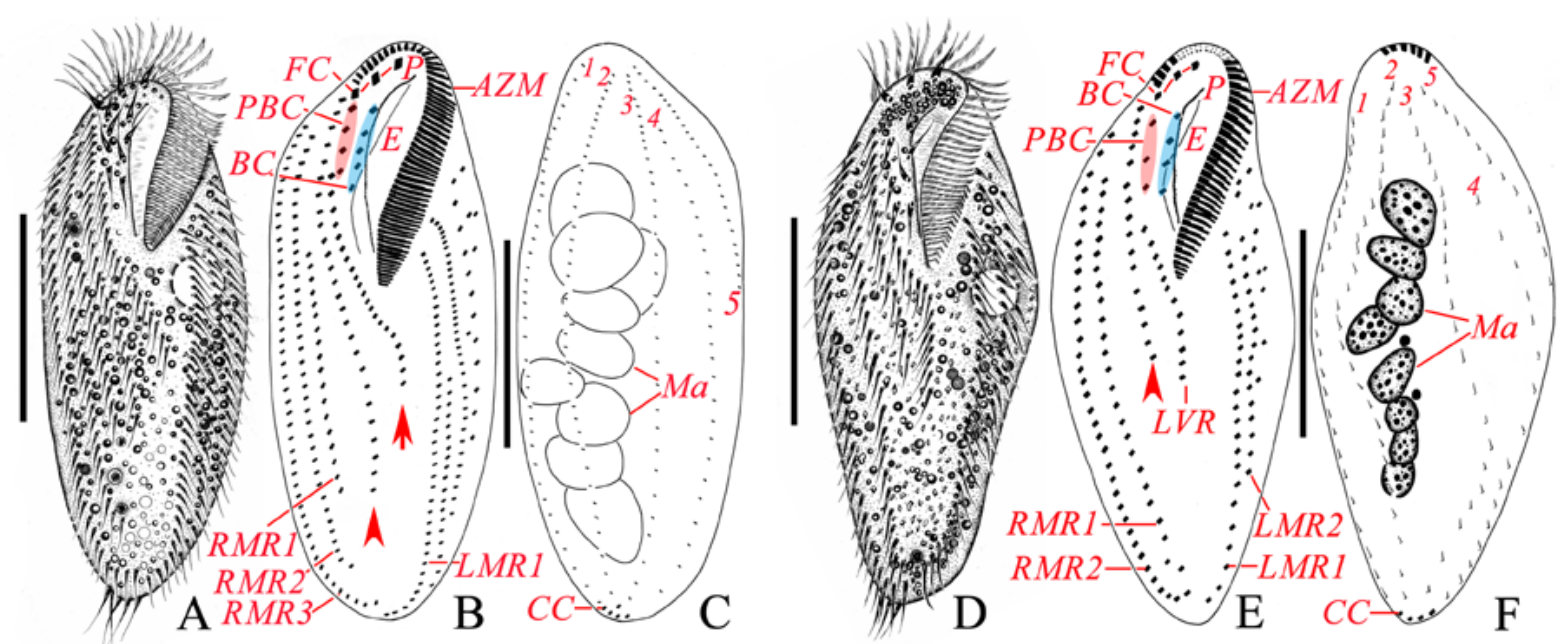

Fig. 2. Morphology of Parakahliella macrostoma pop.1 (A-C) and pop.2 (D-E) from life (A, D) and after protargol staining (B, C, E, F). $(\mathbf{A}, \mathbf{D})$ Ventral views of a representative individual. (B, C, E, F) Infraciliature of ventral and dorsal sides and macronuclear apparatus of specimens, arrowheads mark the right frontoventral row $(\mathbf{B}, \mathbf{E})$ and arrow marks the left frontoventral row (B). AZM, adoral zone of membranelles; CC, caudal cirri; CV, contractile vacuole; E, endoral; FC, frontal cirri; LMR1, 2, left marginal row 1, 2; LVR, left frontoventral row; Ma, macronuclear nodules; P, paroral; PBC, parabuccal cirri; RMR1-3, right marginal row 1-3; RVR, right frontoventral row; 1-5, dorsal kineties. Scale bars: $70 \mu \mathrm{m}$ in A-C and $60 \mu \mathrm{m}$ in D-F.

slightly left of median in middle cell portion, with small chromatin bodies (Figs 2C, F, 3I, 4I). Micronuclei not observed. Locomotion by crawling slowly on substrate using cirri or swimming by rotation about main cell axis.

Adoral zone of membranelles occupying about $40 \%$ (38\% after fixation and staining in pop. 1$)$ and $35 \%(32 \%$ after fixation and staining in pop.2) of body length, composed of 50-78 (on average 65) membranelles in pop. 1 and 40-47 (on average 44) membranelles in pop. 2 (Figs 2B, E, 3H, 4F); cilia in membranelles about $22 \mu \mathrm{m}$ long in vivo. Base of largest adoral membranelles in life about $20 \mu \mathrm{m}$ wide. Paroral and endoral rather long, distinctly curved in the anterior half and intersecting optically (Figs 2B, E, 3H, 4F). Three enlarged frontal cirri in slightly oblique pseudorow, with the right one (cirrus III/3) very close to the distal end of the adoral zone of membranelles; cilia about $20 \mu \mathrm{m}$ long in vivo. Three to five buccal cirri arranged in longitudinal row close to anterior and middle portion of paroral. Parabuccal cirri posterior right frontal cirrus, three or sex in pop. 1 and three or four in pop. 2 (Figs 2B, E, 3H, 4F). Left frontoventral row slightly curved leftwards, commences posterior rearmost parabuccal cirrus about at $25 \%$ of body length in pop. 1 and $37 \%$ in pop. 2 , terminates at $66 \%$ of body length. Right frontoventral row commences slightly ahead of level of anteriormost parabuccal cirrus, terminates at $85 \%$ of body length in pop. 1 and $50 \%$ in pop.2; anterior cirri slightly enlarged (Figs 2B, E, 3H, 4F). Transverse cirri lacking. Inner right marginal row commences about at $35 \%$ of body length in pop. 1 and $25 \%$ in pop. 2 , terminates at $70 \%$ of body length in pop. 1 and $87 \%$ in pop. 2 . Outer right marginal row commences about $15 \%$ of body length, extends along right body margin and terminates at posterior end of cell, slightly separated from innermost left marginal row (Fig. 2B, E). Usually four or five left marginal rows in pop. 1 and three or five in pop.2, becoming progressively shorter posteriorly from innermost to outermost row; innermost row distinctly J-shaped in pop. 1 and lightly curved rightwards in pop.2; outermost row laterally arranged, cirri widely spaced and slightly enlarged (Fig. 2B, E).

Five dorsal kineties; dorsal kineties 1-3 almost bipolar; kinety 4 distinctly shortened, commences about at $10 \%$ of body length in pop. $1,20 \%$ in pop. 2 and terminates at rear cell end; kinety 5 , a dorsomarginal kinety, commences at anterior of body and terminates ahead of mid-body. Three or five (pop.1) and two or four (pop.2) caudal cirri (Figs 2C, F, 4H, 3J).

\section{Morphogenesis during binary fission (Figs 3K-M, 5-7)}

\section{Stomatogenesis}

Opisthe: The first morphogenetic event commences with an oral primordium (OP) just to the left of the middle and posterior portions of the left frontoventral row, 
Table 1. Comparison of characterization of the Gannan (upper line) and Gulang (lower line) populations of Parakahliella macrostomai ${ }^{\text {a }}$

\begin{tabular}{|c|c|c|c|c|c|c|c|}
\hline Character & Min & $\operatorname{Max}$ & Mean & SD & SE & $\mathrm{CV}$ & $\mathrm{n}$ \\
\hline \multirow[t]{2}{*}{ Length of body } & 145 & 210 & 178.2 & 20.9 & 5.4 & 11.7 & 15 \\
\hline & 109 & 203 & 150.4 & 24.5 & 4.9 & 16.3 & 25 \\
\hline \multirow[t]{2}{*}{ Width of body } & 65 & 95 & 81.7 & 10.3 & 2.7 & 12.6 & 15 \\
\hline & 46 & 82 & 64.4 & 9.4 & 1.9 & 14.7 & 25 \\
\hline \multirow[t]{2}{*}{ Length of adoral zone } & 50 & 80 & 68.1 & 9.2 & 2.4 & 13.5 & 15 \\
\hline & 43 & 63 & 59.3 & 8.5 & 1.7 & 14.4 & 25 \\
\hline \multirow[t]{2}{*}{ No. of adoral membranelles } & 50 & 78 & 64.9 & 8.8 & 2.3 & 13.6 & 15 \\
\hline & 40 & 47 & 43.7 & 3.6 & 0.7 & 8.2 & 25 \\
\hline \multirow[t]{2}{*}{ No. of buccal cirri } & 3 & 5 & 4.7 & 0.6 & 0.2 & 12.5 & 15 \\
\hline & 3 & 4 & 3.5 & 0.5 & 0.1 & 14.5 & 25 \\
\hline \multirow[t]{2}{*}{ No. of frontal cirri } & 3 & 3 & 3 & 0 & 0 & 0 & 15 \\
\hline & 3 & 3 & 3 & 0 & 0 & 0 & 25 \\
\hline \multirow[t]{2}{*}{ No. of parabuccal cirri } & 3 & 6 & 4.7 & 0.7 & 0.2 & 14.9 & 15 \\
\hline & 3 & 4 & 3.1 & 0.3 & 0.1 & 9 & 25 \\
\hline \multirow[t]{2}{*}{ No. of cirri in LVR } & 13 & 23 & 18.9 & 2.2 & 0.6 & 11.8 & 15 \\
\hline & 11 & 18 & 14.7 & 1.7 & 0.3 & 11.4 & 25 \\
\hline \multirow[t]{2}{*}{ No. of cirri in RVR } & 20 & 30 & 26.5 & 3 & 0.8 & 11.3 & 15 \\
\hline & 11 & 19 & 15.9 & 2.5 & 0.5 & 15.7 & 25 \\
\hline \multirow[t]{2}{*}{ No. of LMR } & 3 & 5 & 4.2 & 0.7 & 0.2 & 17.1 & 13 \\
\hline & 3 & 5 & 4.1 & 0.7 & 0.1 & 17.2 & 25 \\
\hline \multirow[t]{2}{*}{ No. of cirri in LMR $1^{*}$} & 20 & 42 & 37.2 & 6.9 & 1.9 & 18.7 & 13 \\
\hline & 35 & 15 & 25.8 & 6.4 & 1.3 & 24.8 & 25 \\
\hline \multirow[t]{2}{*}{ No. of cirri in LMR $2^{*}$} & 16 & 38 & 30.7 & 7.6 & 2.1 & 24.6 & 13 \\
\hline & 7 & 23 & 15.4 & 5.3 & 1.1 & 34.4 & 25 \\
\hline \multirow[t]{2}{*}{ No. of cirri in LMR $3^{*}$} & 8 & 25 & 14.5 & 6.9 & 2.1 & 47.3 & 11 \\
\hline & 2 & 19 & 8.8 & 3.4 & 0.7 & 38.6 & 25 \\
\hline \multirow[t]{2}{*}{ No. of cirri in LMR $4^{*}$} & 10 & 16 & 12.4 & 2.6 & 1.2 & 21 & 5 \\
\hline & 13 & 15 & 5.4 & 4.1 & 0.8 & 76.1 & 20 \\
\hline \multirow[t]{2}{*}{ No. of cirri in LMR $5^{*}$} & 4 & 9 & 6.5 & 1.5 & 0.5 & 23.3 & 8 \\
\hline & 2 & 3 & 2.5 & 0.5 & 0.1 & 21.4 & 25 \\
\hline \multirow[t]{2}{*}{ No. of RMR } & 2 & 3 & 2.8 & 0.4 & 0.1 & 13.2 & 13 \\
\hline & 2 & 3 & 2.4 & 0.5 & 0.1 & 20.8 & 25 \\
\hline \multirow[t]{2}{*}{ No. of cirri in RMR $1^{*}$} & 5 & 26 & 11 & 6.1 & 1.7 & 55 & 13 \\
\hline & 10 & 33 & 15.9 & 5 & 1 & 31.6 & 25 \\
\hline \multirow[t]{2}{*}{ No. of cirri in RMR 2* } & 21 & 45 & 31.3 & 6.2 & 1.6 & 19.7 & 15 \\
\hline & 7 & 36 & 28.6 & 7 & 1.6 & 24.7 & 25 \\
\hline \multirow[t]{2}{*}{ No. of cirri in RMR $3^{*}$} & 25 & 48 & 39.5 & 6.5 & 1.7 & 16.5 & 15 \\
\hline & 12 & 37 & 29.4 & 8.5 & 1.6 & 28.9 & 11 \\
\hline \multirow[t]{2}{*}{ No. of caudal cirri } & 3 & 5 & 3.1 & 0.5 & 0.1 & 16.5 & 15 \\
\hline & 2 & 4 & 3.3 & 0.5 & 0.1 & 16.4 & 25 \\
\hline \multirow[t]{2}{*}{ No. of dorsal kineties } & 5 & 5 & 5 & 0 & 0 & 0 & 10 \\
\hline & 5 & 5 & 5 & 0 & 0 & 0 & 25 \\
\hline \multirow[t]{2}{*}{ No. of macronuclear nodules } & 10 & 8 & 8.8 & 0.6 & 0.2 & 6.4 & 15 \\
\hline & 4 & 9 & 7.7 & 1.3 & 0.3 & 17.4 & 25 \\
\hline
\end{tabular}

${ }^{\text {a }}$ All data are based on protargol-stained specimens. Measurements in $\mu \mathrm{m}$.

Abbreviations: LMR, left marginal row; LVR, left frontoventral row; Max, maximum; Mean, arithmetic mean; Min, minimum; $n$, number of cells measured; RMR, right marginal row; RVR, right frontoventral row; SD, standard deviation.

* numbered from innermost to outermost. 


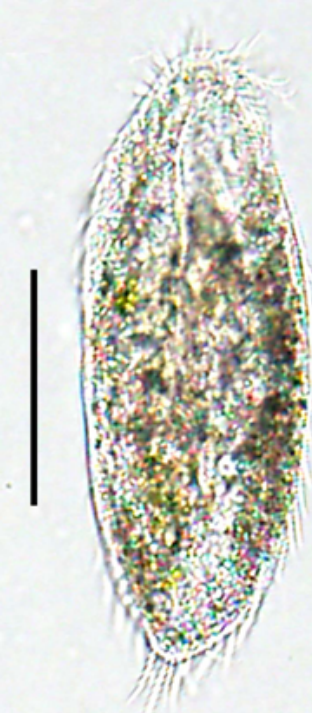

A
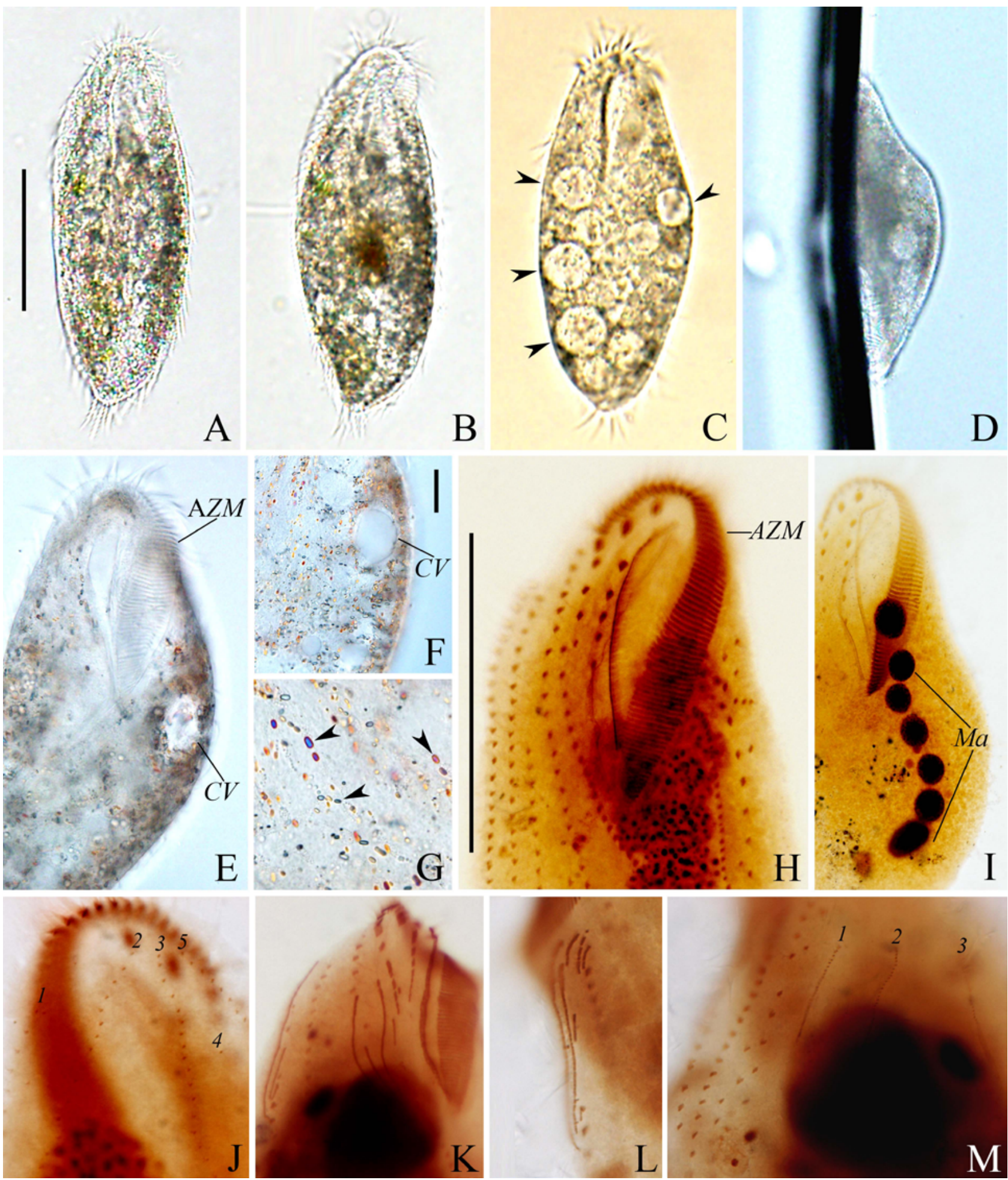

Fig. 3. Photomicrographs of Parakahliella macrostoma pop.1 from life (A-G) and after protargol staining (H-M). (A) ventral view of a representative specimen. (B, C) ventral views of a different individuals in B and food vacuoles (arrowheads). (D) lateral view in vivo. (E, F) body portion in ventral views showing adoral zone of membranelles and contractile vacuole position. (G) detail of crystals (arrowheads) in the cytoplasm. (H) anterior body portion in ventral view showing adoral zone of membranelles. (I) anterior body in ventral view showing macronuclear nodules. (J) dorsal view of anterior body portion showing the dorsal kineties. (K-M) ventral and dorsal views of a mid-stage divide. AZM, adoral zone of membranelles; CV, contractile vacuole; Ma, macronuclear nodules; $1-5$, dorsal kineties. Scale bars: $130 \mu \mathrm{m}$ in $\mathrm{A}, \mathrm{H}$ and $20 \mu \mathrm{m}$ in $\mathrm{F}$. 

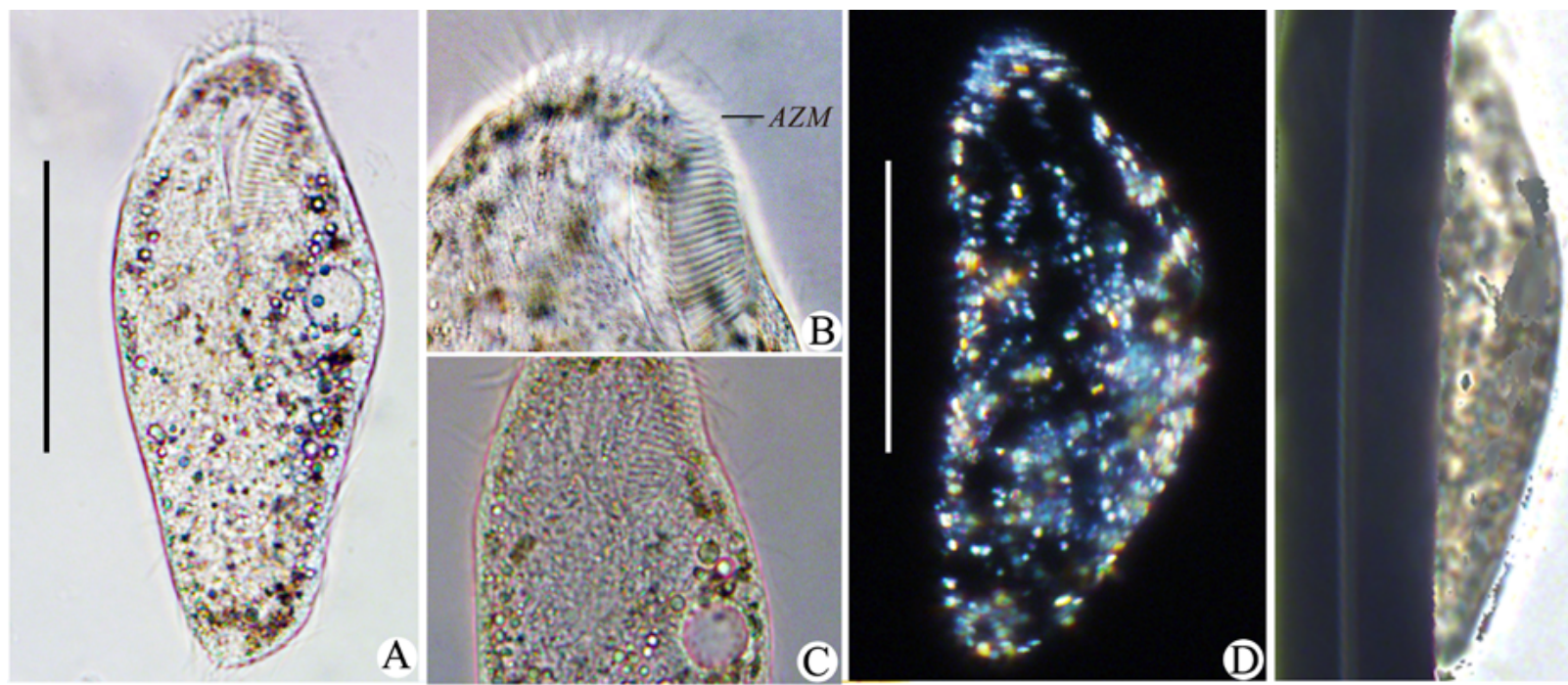

E
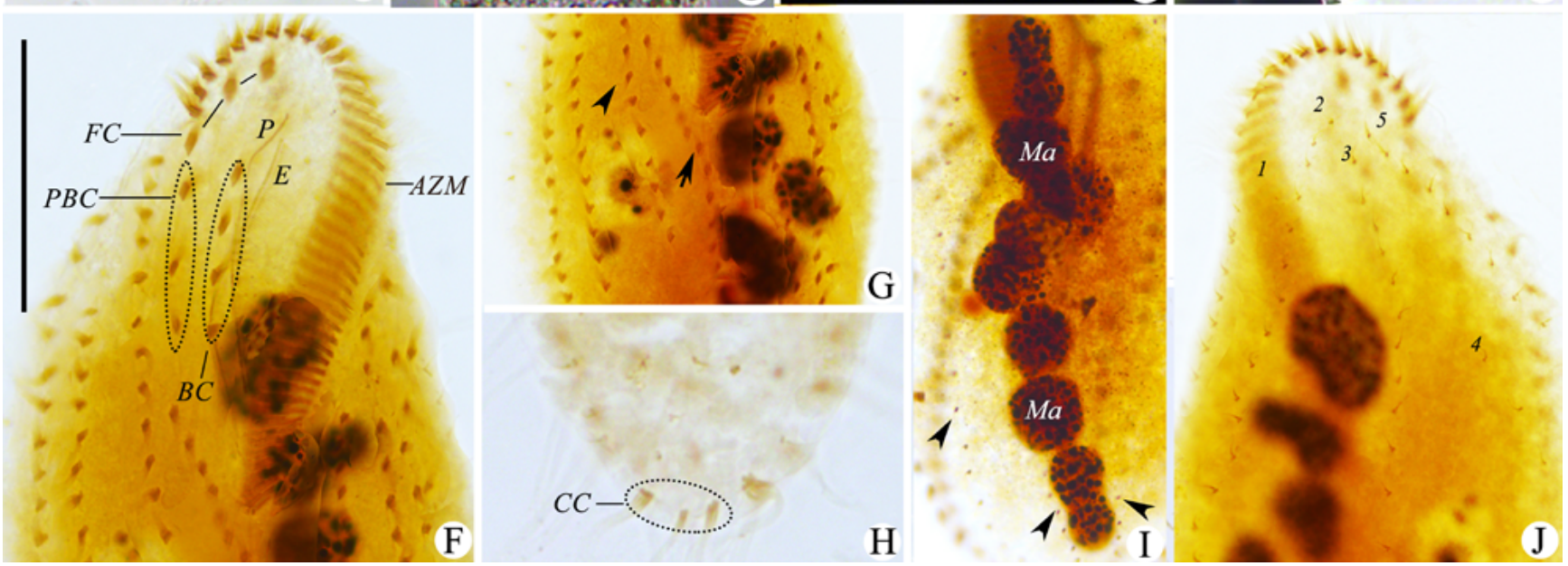

Fig. 4. Photomicrographs of Parakahliella macrostoma pop. 2 from life (A-E) and after protargol staining (F-J). (A) ventral view of typical individual. (B, C) ventral views of the anterior portion showing adoral zone of membranelles in B and contractile vacuole in C. (D) a different individual under the polarizing microscope (POL) showing the crystals in the cytoplasm. (E) lateral view in vivo. (F) anterior body portion in ventral view; dotted ellipses indicate the buccal and parabuccal cirri; also showing the frontal cirri, endoral, paroral, and adoral zone of membranelles. (G) a part of body in ventral view, arrow indicates the left frontoventral row, arrowhead marks the right frontoventral row. (H) dorsal view of the posterior portion showing caudal cirri. (I) body portion in dorsal view showing macronuclear nodules, arrowheads mark the dorsal kineties. (J) anterior body portion in dorsal view showing dorsal kineties. AZM, adoral zone of membranelles; BC, buccal cirri; CC, caudal cirri; CV, contractile vacuole; E, endoral; FC, frontal cirri; Ma, macronuclear nodules; P, paroral; PBC, parabuccal cirri; $1-5$, dorsal kineties. Scale bars: $80 \mu \mathrm{m}$ in $\mathrm{A}, 60 \mu \mathrm{m}$ in $\mathrm{D}, \mathrm{E}$ and $30 \mu \mathrm{m}$ in $\mathrm{F}$.

which possibly develops de novo (Figs 5A, 7A). During this process, most parental frontoventral cirri remain intact and some left frontoventral cirri are either resorbed or dedifferentiated (Fig. 7A). As the number of basal bodies increases, a relatively elongated anarchic field is formed posterior to the buccal cavity. Thereafter, the OP develops and differentiates new membranelles posteriad. Simultaneously, the anlage for the undulating membranes (UM-anlage) forms to the right of the $\mathrm{OP}$ as a long streak of basal bodies (Figs 5B, 7B, C). Later, the anterior end of the newly developed adoral zone of membranelles (AZM) bends to the right, completing the differentiation of membranelles and forming the new oral structure for the opisthe (Figs 5D, F, H, 7H). The leftmost frontal cirrus is derived from the anterior end of the UM-anlage (Figs 5B, D, F, H, 7D-H). Subsequently, the UM-anlage splits longitudinally into two streaks from which the endoral and paroral are formed (Figs 5H, 6A, C, 7G, H). 

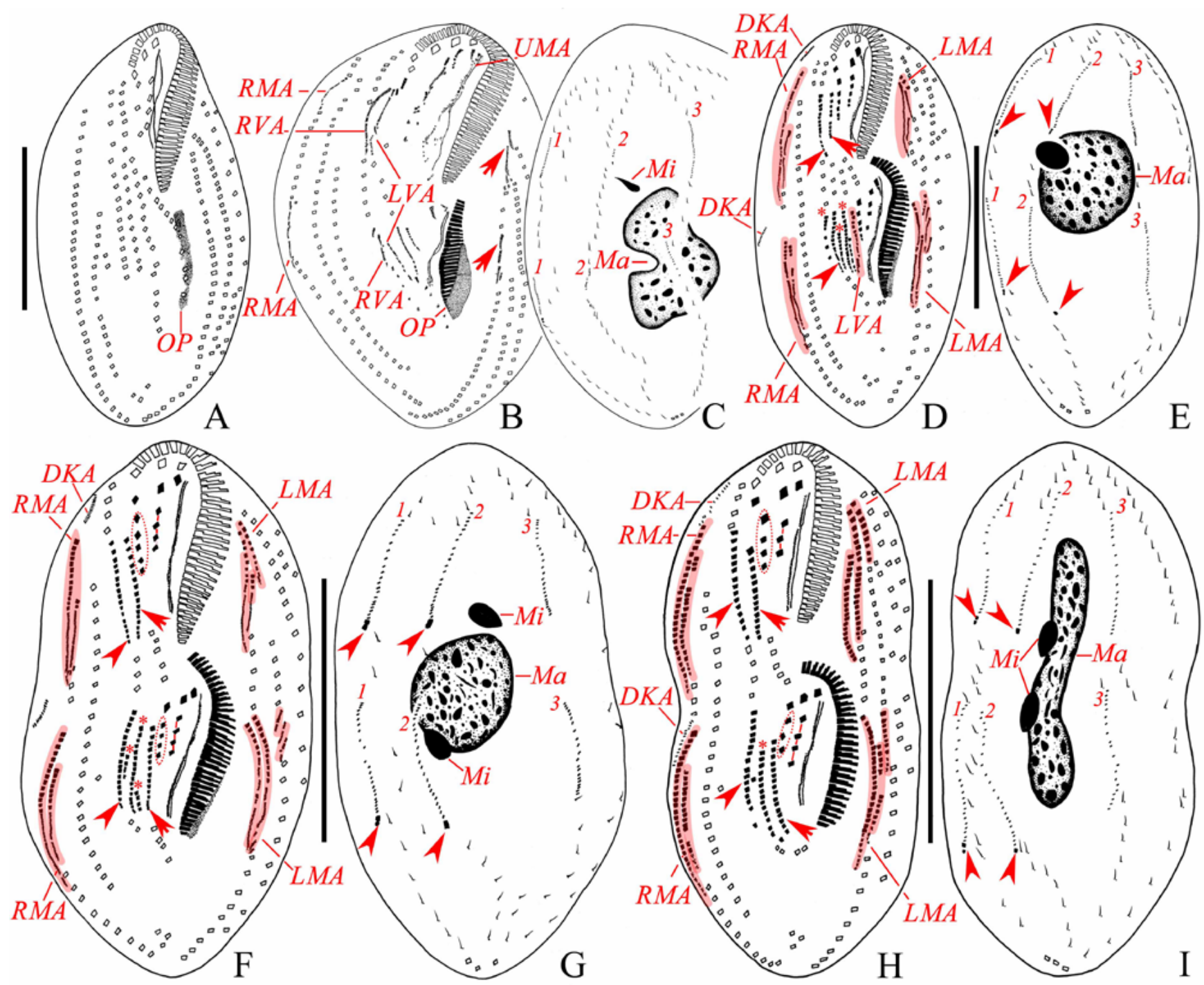

Fig. 5. Morphogenesis in Parakahliella macrostoma pop. 2 from early to late stages (after protargol staining). (A) early divider, showing the oral primordium. (B-G) middle divider. (H, I) late divider. Arrows in (B) mark the left marginal anlagen; arrows point to the left frontoventral row primordia $(\mathbf{D}, \mathbf{F}, \mathbf{H})$, arrowheads indicate the right frontoventral row primordia $(\mathbf{D}, \mathbf{F}, \mathbf{H})$ and the newly formed caudal cirri $(\mathbf{E}, \mathbf{G}, \mathbf{I})$; short lines connect buccal cirri $(\mathbf{F}, \mathbf{H})$, dotted ellipses indicate the parabuccal cirri $(\mathbf{F}, \mathbf{H})$; asterisks mark the additional frontoventral streaks (D, F, H). DKA, dorsal kineties anlagen; LMA, left marginal anlagen; Ma, macronuclear nodules; Mi, micronuclei; OP, oral primordium; RMA, right marginal anlagen; UMA, undulating membrane anlage; 1-3, dorsal kineties anlagen. Scale bars: $100 \mu \mathrm{m}$ in A, D, E and 120 $\mu \mathrm{m}$ in $\mathrm{F}-\mathrm{I}$.

Proter: Examples of only the middle and late stages of the proter were observed. At the middle stage, the UM-anlage forms by differentiation of the anterior portion of the parental paroral and endoral (Figs 5B, 7B). In subsequent stages, the basic development of the UM-anlage follows a similar pattern to that in the opisthe (Figs 5B, D, F, H, 6A, C). During this process, the parental AZM remains unchanged.
Development of the anlagen of the frontal-ventral cirri: From the earliest stage observed, five thread-like frontal-ventral cirral anlagen (FVT-anlagen) are formed in both proter and opisthe (Figs 5B, 7B). The origin of the frontal-ventral primordia for the proter is as follows: anlage I originates from the old undulating membranes; anlage II forms from some or all of the buccal cirri; anlage III comes from the second parabuccal cirrus; 

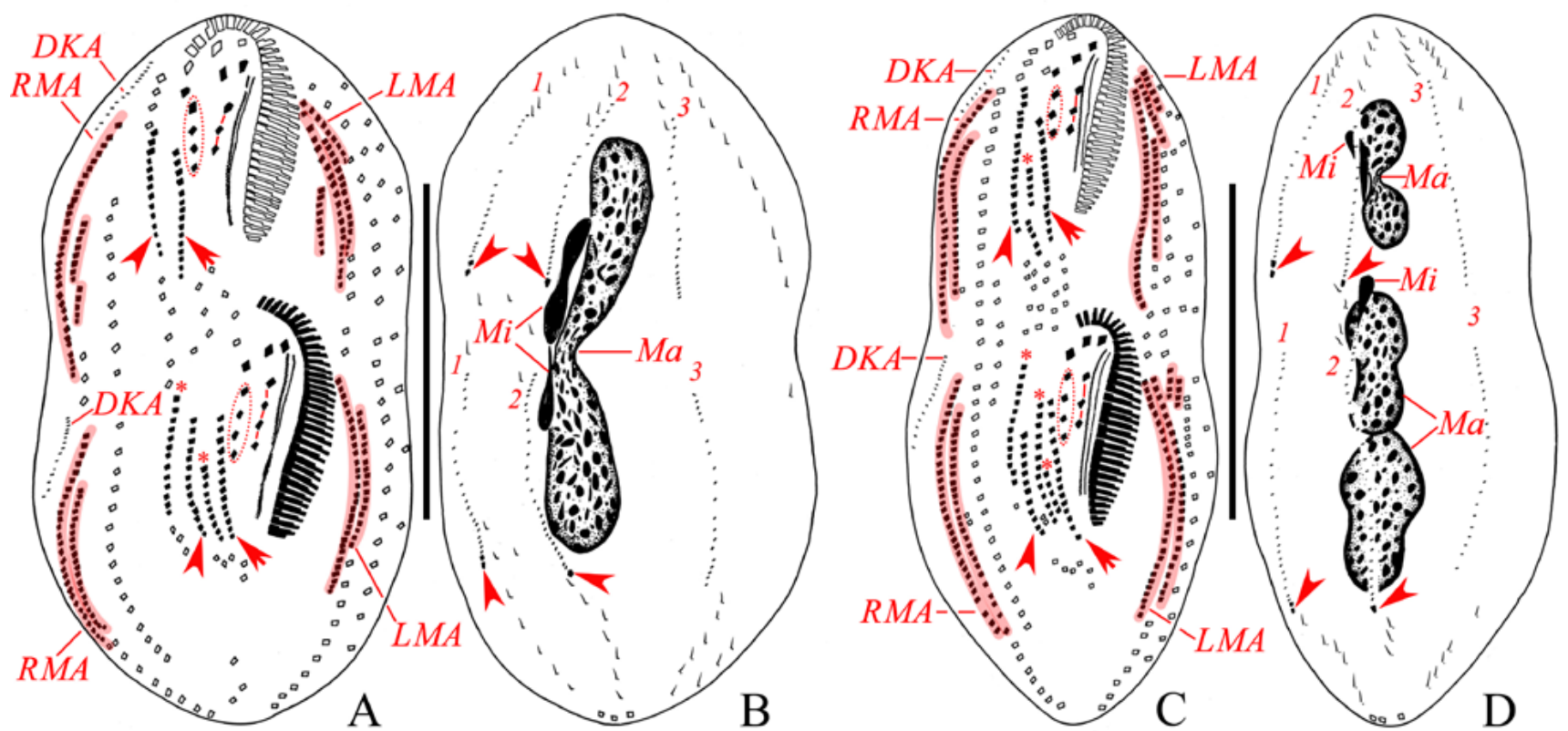

Fig. 6. Late dividers of Parakahliella macrostoma pop.2, after protargol staining. (A-D) late divider, arrows mark the newly formed left frontoventral row and arrowheads indicate the newly formed right frontoventral row $(\mathbf{A}, \mathbf{C})$; arrowheads mark the newly formed caudal cirri (B, D); short lines connect buccal cirri, dotted ellipses indicate the parabuccal cirri; asterisks mark the additional frontoventral streak (A, C). DKA, dorsal kineties anlagen; LMA, left marginal anlagen; Ma, macronuclear nodules; Mi, micronuclei; RMA, right marginal anlagen; 1-3, dorsal kineties anlagen. Scale bars: $120 \mu \mathrm{m}$.

anlage IV is derived from some cirri of the anterior part of the left frontoventral row; and anlage $\mathrm{V}$ originates from some cirri of the anterior part of the right frontoventral row. The primordia of the opisthe originate as follows: anlage I comes from the oral primordium; anlage II originates independently to the left of the left frontoventral row; anlage III originates from the posterior part of the left frontoventral row; anlage IV seems to develop de novo; anlage $\mathrm{V}$ is derived from the posterior part of the right frontoventral row. Both in the proter and in the opisthe, five FVT-anlagen are usually recognizable. Occasionally, an additional anlage occurs to the right or to the left of anlage $\mathrm{V}$ (Figs 3K, L, 5D, F, H, 6A, C, 7D-H). Later, five anlagen are lengthened and form cirri. Anlage I forms the left frontal cirrus and the undulating membranes; anlage II forms the middle frontal cirrus and the buccal cirri; anlage III forms the right frontal cirrus and the parabuccal cirri; the left and right frontoventral rows originate from anlagen IV and $\mathrm{V}$, respectively.

At a late stage, the divider begins to elongate and the new ciliary structures move further apart as they migrate toward their final positions (Figs $5 \mathrm{H}, 6 \mathrm{~A}, \mathrm{C}$ ). Meanwhile, the parental structures are gradually re- sorbed, the cytostomes of the daughter cells are completed, and the daughter cells begin to separate with the formation of an equatorial furrow (Fig. 6A, C).

Marginal cirri: Some cirri behind the anteriormost cirri of the outer right and the anteriormost cirri of the inner left marginal row are modified to the proter's marginal cirral primordia. The middle regions of the same rows were already incorporated in the primordia of the opisthe (Fig. 5B). A conspicuous morphogenetic event was the occurrence of additional streaks within each marginal primordium (Fig. 5D). The parental inner right and outer left marginal row(s) - they do not produce primordia - and short fragments of the parental ventral rows were still preserved (Figs 5D, F, H, 6A, C). Finally, all marginal cirral anlagen generate new cirri that replace the parental structures (Fig. 6C).

Dorsal ciliature: The new dorsal kineties 1-3 obviously originate via intrakinetal anlagen within the parental rows 1,2, and 3. Caudal cirri are formed at the end of the new kineties 1 and 2. The old dorsal kineties 1-3 are nearly completely resorbed, while the kinety 4 was fully retained. The new kinety 5 originates dorsomarginally (Figs 3M, 5E, G, I, 6B, D). 

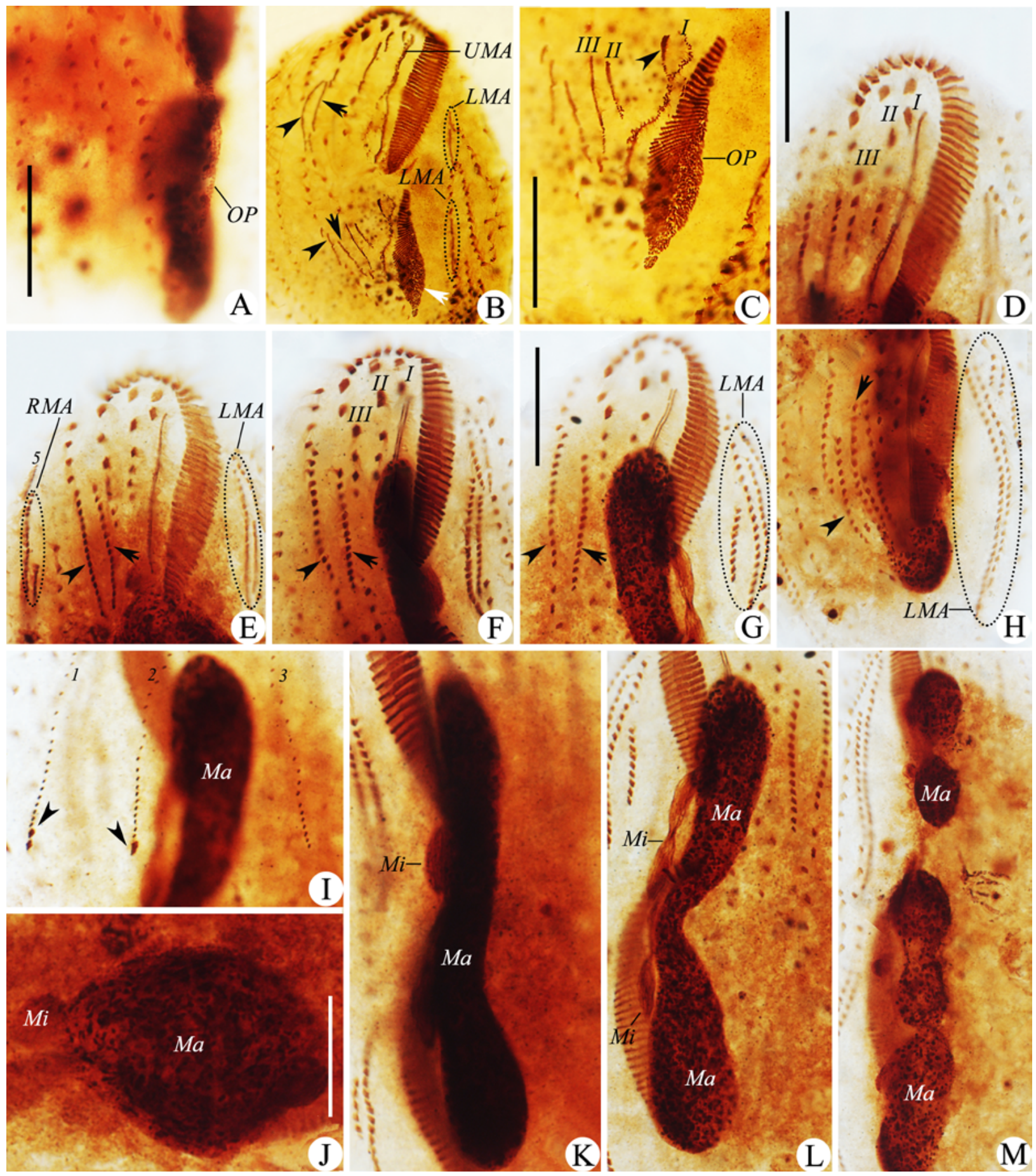

Fig. 7. Photomicrographs of dividers of Parakahliella macrostoma pop. 2 during divisional morphogenesis (after protargol staining). (A) ventral view of early divider showing oral primordium, arrowheads point to the left frontoventral cirri. (B, C) ventral views of late divider, arrows mark the left frontoventral row anlagen, white arrow indicates the oral primordium, arrowheads mark the right frontoventral row anlagen (B) arrowheads in C point to the undulating membrane anlage. (D-G) ventral views of late dividers of proter, arrows indicate the newly formed left frontoventral row, arrowheads mark the newly formed right frontoventral row. (H) ventral view of late divider of opisthe, arrow indicates the newly formed left frontoventral row, arrowhead marks the newly formed right frontoventral row. (I) dorsal view of anterior portion showing the dorsal kineties anlagen, arrowheads mark new caudal cirri. (J-M) dorsal views of the body portion showing the macronuclear nodules fused to a single mass (J) and divider (K-M). LMA, left marginal anlagen; Ma, macronuclear nodules; Mi, micronuclei; OP, oral primordium; RMA, right marginal anlagen; UMA, undulating membrane anlage; I-III, frontoventral transverse cirral anlagen I-III. Scale bars: $25 \mu \mathrm{m}$ in A, C, $30 \mu \mathrm{m}$ in D, G and $20 \mu \mathrm{m}$ in J. 
Division of nuclear apparatus: The division of the nuclear apparatus proceeds as in most other hypotrichs. Briefly, the macronuclear nodules fuse to form a single mass midway through morphogenesis and then separate into many nodules; micronucleus begin stretching and connected by a thin filament in the late stage, finally separate. (Figs 5E, G, I, 6B, D, 7I-M).

\section{SSU rRNA gene sequence and phylogenetic analyses} (Fig. 8)

The lengths of the SSU rRNA gene sequence of Parakahliella macrostoma pop.1 and pop.2 (GenBank accession number KP266626, MH393767) are 1620bp and $1725 \mathrm{bp}$, respectively. And the $\mathrm{G}+\mathrm{C}$ contents are $46.42 \%$ and $45.62 \%$, respectively. The similarity of these two sequences is $99.8 \%$.

The topologies of the ML and BI trees are almost concordant; thus only topology of the ML tree with support values for both analyses is presented (see Fig. 8 $\mathrm{ML} / \mathrm{BI}$ ). In the phylogenetic trees, species of the family Kahliellidae are separated into three clades. Parakahliella macrostoma pop. 1 and pop. 2 cluster in a clade with maximum supports ( $100 \% \mathrm{ML}, 1.00 \mathrm{BI})$, which is sister to a group of the family Oxytrichidae comprising

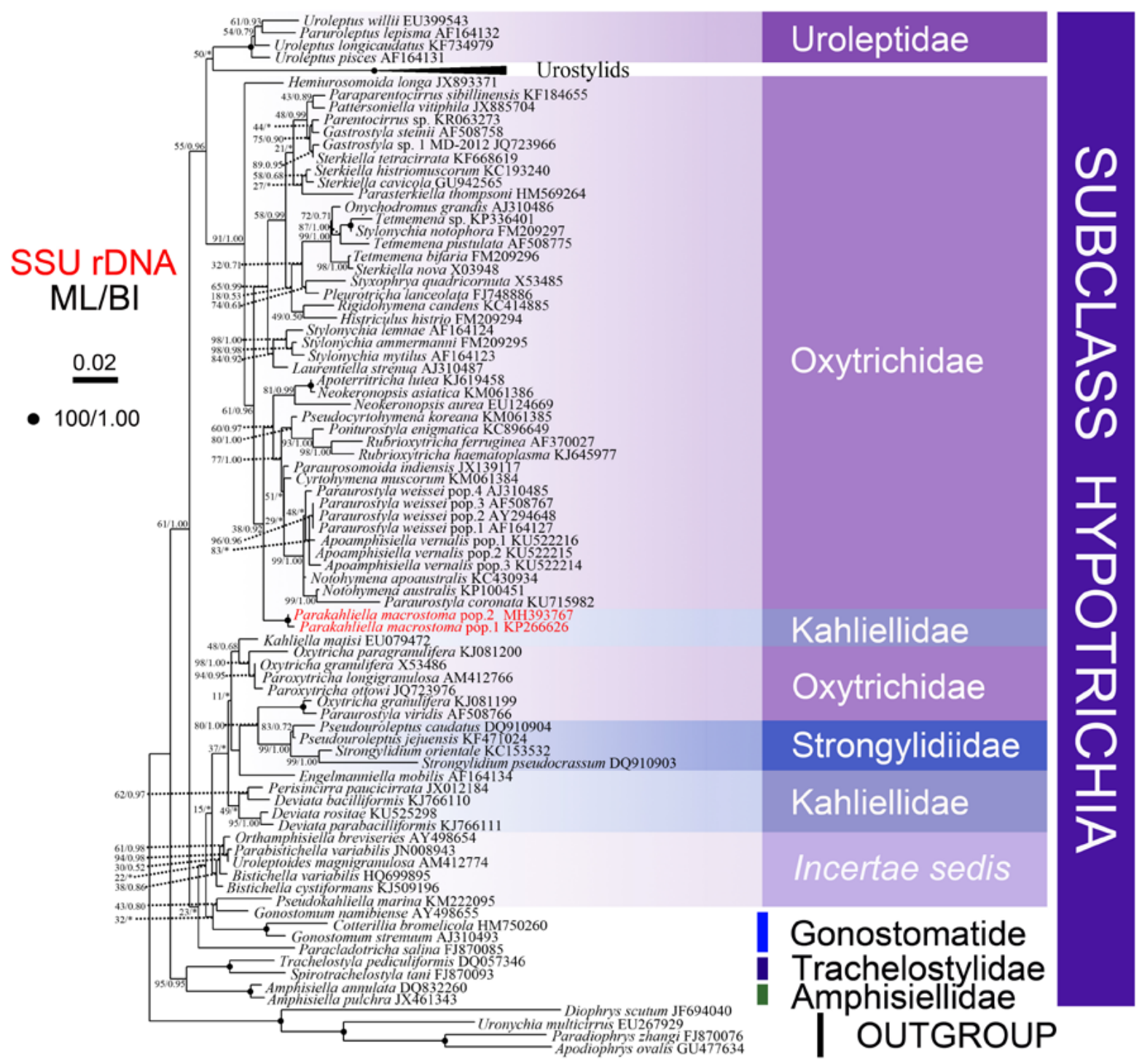

Fig. 8. Maximum likelihood (ML) phylogenetic tree based on the small subunit rRNA (SSU rRNA) gene sequences. Numbers at nodes represent the bootstrap values of maximum likelihood analysis out of 1,000 replicates and the posterior probability of Bayesian analysis. “*” indicates the disagreement between BI tree and the reference ML tree. All branches are drawn to scale; scale bar corresponds to two substitutions per 100 nucleotide positions. 
Pseudocyrtohymena, Ponturostyla, Rubrioxytricha, Paraurosomoida, Cyrtohymena, Notohymena, Apoterritricha, Paraurostyla, Apoamphisiella and Neokeronopsis. Kahliella matisi, which represents the type genus of the family Kahliellidae, clusters with Oxytricha and Paroxytricha. Engelmanniella mobilis, which is also a species of Kahliellidae, and then is sister to the clade containing the family Strongylidiidae and two other Oxytrichidae species. Together these two clades make a group which is sister to the clade of remaining four Kahlielledae species comprising Deviata spp. and Perisincirra spp. All these three branches form a clade which shows sister relationship with the clade of five species that the phylogenetic positions are still unresolved including Orthamphisiella breviseries, Parabistichella variabilis, Uroleptoides magnigranulosa and Bistichella spp.

\section{DISCUSSION}

\section{Identification of Chinese populations of Parakahli- ella macrostoma}

Parakahliella macrostoma was described by Foissner (1982) from the Lower Austrian lowland and redescribed by Berger et al. (1985) from the alpine soil (Berger 2011). The in vivo morphology and ciliature (Fig. 2, Table 1) of Chinese isolates are similar to the previous descriptions, combination the ontogenesis, so we can identity the Chinese isolates were Parakahliella macrostoma.

\section{Morphometric comparison with related taxa}

Our populations can be easily distinguished from Parakahliella haideri by the number of left marginal rows (3-5 vs. 1) and the number of adoral membranelles (44, 65 vs. 28). Compared with P. terricola, our populations have: (1) more adoral membranelles (44, 65 vs. 28 ); (2) more caudal cirri (3-5 vs. 3); (3) less fragmented frontoventral and right marginal rows.

\section{Morphogenetic comparison with previous popula- tion}

In present work, we observed several stages of divisional morphogenesis. The main features of the morphogenetic process are: (1) the parental adoral zone of membranelles is retained completely by the proter and the anlage of undulating membranes originates from dedifferentiation of the old structures; (2) the morphogenesis of the dorsal kineties is simpler than the Oxytricha pattern, i.e. without fragmentation of the dorsal kinety 3 anlage; (3) five thread-like FVT-anlagen are formed in both daughter cells; (4) the marginal rows develop intrakinetally; (5) the macronuclear nodules fuse into a single mass during the mid-stage of morphogenesis.

The morphogenetic process of Parakahliella macrostoma was first reported by Berger et al. (1985) compared to which our populations differ in two respects: (1) opisthe's anlage II originates independently to the left of the left frontoventral row $v s$. from oral primordium; (2) opisthe's anlage IV seems to develop de novo vs. from middle part of left frontoventral row. Compared with Apoamphisiella, our populations can be distinguished by: the fragmentation of dorsal kinety 3 vs. no fragmentation; Our populations differ from Bistichella by: five FVT-anlagen vs. six FVT-anlagen; compared with Parabistichella, our populations can be distinguished by: five dorsal kineties vs. dorsal kinety pattern of Gonostomum-type; Our populations differ from Paraurostyla by: five FVT-anlagen vs. more than six FVT-anlagen.

\section{Phylogenetic analyses}

Originally, Foissner (1982) assigned Parakahliella macrostoma to Paraurostyla Borror, 1972, a genus classified in the oxytrichids based on some features of the ventral morphogenesis. Berger et al. (1985) classified Parakahliella in the Kahliellidae because it is consistent with the key diagnostic features of kahliellids, namely, meridionally arranged cirral rows and lacking transverse cirri (Tuffrau 1979). This classification was widely accepted (Eigner 1995; Foissner 1998; Jankowski 2007; Lynn 2008; Lynn and Small 2002; Tuffrau 1987; Tuffrau and Fleury 1994).

Our phylogenetic analyses showed that two Parakahliella macrostoma populations did not group with Kahliella, the name-bearing type of the Kahlielledae, though the genus Parakahliella was classified in the family Kahliellidae in the system of Lynn (2008). Parakahliella and Kahliella differ in several respects including: (1) pattern of AZM (Oxytricha pattern vs. Gonostomum pattern); (2) undulating membranes long, curved, and optically intersecting vs. endoral relatively long, paroral rather short, not intersecting; (3) buccal field (broad vs. narrow); (4) caudal cirri (present vs. lacking).

Parakahliella clusters with the subfamily Oxytrichinae in our phylogenetic trees (Figure 8). This could be confirmed by the common morphological characters 
Table 2. Comparison of various populations of Parakahliella macrostoma

\begin{tabular}{|c|c|c|c|c|}
\hline Character & 1 & 2 & 3 & 4 \\
\hline Body, length in vivo $(\mu \mathrm{m})$ & $170-220$ & $140-160$ & $160-235$ & $135-180$ \\
\hline Body, width in vivo $(\mu \mathrm{m})$ & $50-70$ & $50-55$ & $60-100$ & $55-85$ \\
\hline Length:width in vivo & $3.1: 1$ & $2.9: 1$ & $2.7: 1$ & $2.5: 1$ \\
\hline Ratio of AZM in vivo & $38 \%$ & - & $40 \%$ & $35 \%$ \\
\hline Body, length (protargol) $(\mu \mathrm{m})$ & $86-130(106.4)$ & $98-171(127.4)$ & $145-210(178.2)$ & $110-205(140.3)$ \\
\hline Body, width (protargol) $(\mu \mathrm{m})$ & $28-53(40.3)$ & $27-61(38.4)$ & $65-95(81.7)$ & $45-85(64.3)$ \\
\hline Length:width ratio (protargol) & $3: 1$ & $3: 1$ & $2: 1$ & $2: 1$ \\
\hline AZM, length (protargol) $(\mu \mathrm{m})$ & $27-50(40.7)$ & $32-76(44.5)$ & $50-80(68.1)$ & $43-63(56.1)$ \\
\hline No. of AZM & $38-61(52.5)$ & $40-75(50.8)$ & $50-78(64.9)$ & $40-47(43.5)$ \\
\hline No. of cirri in $\mathrm{BC}$ & $3-6(3.9)$ & $2-5(3.0)$ & $3-5(4.7)$ & $3-4(3.5)$ \\
\hline No. of cirri in $\mathrm{FC}$ & 3 & 3 & 3 & 3 \\
\hline No. of cirri in LVR & $14-35(24.7)$ & $13-24(17.3)$ & $13-23(18.9)$ & $11-18(14.5)$ \\
\hline No. of cirri in RVR & $18-33(24.8)$ & $13-27(17.4)$ & $20-30(26.5)$ & $11-19(15.3)$ \\
\hline No. of LMR & $4-5(4.2)$ & $2-5(2.9)$ & $3-5(4.2)$ & $3-5(4.1)$ \\
\hline No. of cirri in LMR 1 & $19-35(29.6)$ & $14-47(25.0)$ & $20-42(37.2)$ & $15-35(25.3)$ \\
\hline No. of cirri in LMR 2 & $13-29(20.7)$ & $10-27(16.5)$ & $16-38(30.7)$ & $7-23(16.1)$ \\
\hline No. of cirri in LMR 3 & $7-20(15.4)$ & $3-29(8.7)$ & $8-25(14.5)$ & $2-19(8.1)$ \\
\hline No. of cirri in LMR 4 & $3-13(5.9)$ & $5-8(6.7)$ & $10-16(12.4)$ & $13-15(10.9)$ \\
\hline No. of cirri in LMR 5 & - & - & $4-9(6.5)$ & $2-3(2.3)$ \\
\hline No. of RMR & 2 & 2 & $2-3(2.8)$ & $2-4(2.5)$ \\
\hline No. of cirri in RMR 1 & $18-35(22.8)$ & $8-25(16.3)$ & $5-26(11.0)$ & $10-33(15.1)$ \\
\hline No. of cirri in RMR 2 & $25-40(33.6)$ & $13-37(29.2)$ & $21-45(31.3)$ & $7-36(28.1)$ \\
\hline No. of cirri in RMR 3 & - & - & $25-48(39.5)$ & $12-37(27.6)$ \\
\hline No. of CC & $4-6(5)$ & $3-7(4.8)$ & $3-5(3.1)$ & $2-4(3.3)$ \\
\hline No. of DK & 5 & 5 & 5 & 5 \\
\hline No. of Ma & $8-13(10.6)$ & $5-10(7.4)$ & $8-10(8.8)$ & $4-9(7.3)$ \\
\hline Habitat & Terrestrial & Terrestrial & Terrestrial & Terrestrial \\
\hline Data source & Berger (2011) & Berger (2011) & Present work & Present work \\
\hline
\end{tabular}

- data not available.

AZM, adoral zone of membranelles; BC, buccal cirri; CC, caudal cirri; DK, dorsal kineties; FC, frontal cirri; LMR, left marginal row; LVR, left frontoventral row; Ma, macronuclear nodules; RMR, right marginal row; RVR, right frontoventral row. Population: 1, Austrian population; 2, Alpine population; 3, Gannan population; 4, Gulang population.

shared by $P$. macrostoma and the subfamily Oxytrichinae: (1) adoral zone of membranelles formed like a question mark; (2) three frontovental cirri; (3) undulating membranes long, curved, and optically intersecting; (4) body flexible, but not distinctly contractile; (5) dorsomarginal kinety present. Furthermore, the two Parakahliella macrostoma populations are closely related to Apoamphisiella and all morphospecies of Paraurostyla but Paraurostyla viridis, a possibly misidentified Oxytricha granulifera strain according to Berger (2006) and Paiva et al. (2009).
Deviata and Perisincirra paucicirrata cluster together, but are far from the two Parakahliella macrostoma populations. The two Chinese populations of P. macrostoma differ from Deviata in having: (1) adoral zone of membranelles and undulating membranes in Oxytricha pattern (vs. Gonostomum pattern); (2) more buccal cirri and parabuccal cirri (3-4 vs 1, 3-5 vs 1, respectively); (3) more macronuclear nodules, i.e. 8-10 (pop.1) and 4-9 (pop.2) vs 4; (4) more dorsal kineties (5 vs 2); (5) caudal cirri present ( $v s$ absent). Our populations can be separated from Perisincirra by having: (1) adoral 
zone of membranelles and undulating membranes patterns in Oxytricha pattern (vs. Gonostomum pattern); (2) more buccal cirri and parabuccal cirri number (3-4 vs 1, 3-5 vs 2, respectively); (3) more macronuclear nodules i.e., 8-10 (pop.1) vs 2, 4-9 (pop.2) vs 2; (4) more dorsal kineties (5 vs 3) (Li et al. 2013; Luo et al. 2016).

At present, the positions of Parabistichella variabilis, Bistichella variabilis and Bistichella cystiformans are still unresolved. In our phylogenetic analyses, these three isolates are far from Parakehliella macrostoma, albeit they have so many similar morphologic features with Parakahliella macrostoma such as: (1) adoral zone of membranelles and undulating membranes in Oxytricha pattern; (2) more than one buccal cirri and parabuccal cirri; (3) have front ventral row. To assess the phylogeny of Parabistichella and Bistichella, we enforce the monophyly of two Parakehliella macrostoma strains, Parabistichella variabilis, Bistichella variabilis and Bistichella cystiformans, and we also perform the approximately unbiased (AU) test. However, the AU test result rejects its monophyly ( $p=1 \mathrm{e}-053)$, consequently, additional molecular data and more detailed ontogenetic information are needed for inferring exact phylogeny of Parabistichella spp. and Bistichella spp.

Acknowledgements. This work was supported by the National Natural Science Foundation of China (project numbers: 41761056, 41361055, 31522051, 31471973), the International Research Group Program (IRG14-22), Deanship of Scientific Research at King Saud University for funding this work through Research Group (RGP-242) and the Project for Enhancing the Research Capability of Young Teachers in Northwest Normal University (NWNULKQN-16-11). Many thanks are given to Professor Weibo Song, OUC, anonymous reviewers, and the associate editor for their constructive suggestions, and to Miss. Huiru Zhang and Mr. Guanhong Wan for sampling.

\section{REFERENCES}

Berger H. (1999) Monograph of the Oxytrichidae (Ciliophora, Hypotrichia). Monogr. Biol. 78: 1-1080

Berger H. (2006) Monograph of the Urostyloidea (Ciliophora, Hypotricha). Monogr. Biol. 85: 1-1303

Berger H. (2008) Monograph of the Amphisiellidae and Trachelostylidae (Ciliophora, Hypotricha). Monogr. Biol. 88: 1-737

Berger H. (2011) Monograph of the Gonostomatidae and Kahliellidae (Ciliophora, Hypotricha). Monogr. Biol. 90: 1-741

Berger H., Foissner W., Adam H. (1985) Morphological variation and comparative analysis of morphogenesis in Parakahliella macrostoma (Foissner, 1982) nov. gen. and Histriculus muscorum (Kahl, 1932), (Ciliophora, Hypotrichida). Protistologica 21: 295-311

Chen L. Y., Zhao X., Shao C., Miao M., Clamp J. (2017a) Morphology and phylogeny of two new ciliates, Sterkiella sinica sp. nov. and Rubrioxytricha tsinlingensis sp. nov. (Protozoa,
Ciliophora, Hypotrichia) from north-west China. Syst. Biodivers. 15: 131-142

Chen X. M., Lu X. T., Luo X. T., Jiang J, Shao C., Al-Rasheid K. A. S., Warren A., Song W. B. (2017b) The diverse morphogenetic patterns in spirotrichs and philasterids: Researches based on five-year-projects supported by IRCN-BC and NSFC. Eur. J. Protistol. 61: 439-452

Dong J., Lu X. T., Shao C., Huang J., Al-Rasheid K. A. S. (2016) Morphology, morphogenesis and molecular phylogeny of a novel saline soil ciliate Lamtostyla salina n. sp. (Ciliophora, Hypotricha). Eur. J. Protistol. 56: 219-231

Eigner P. (1995) Divisional morphogenesis in Deviata abbrevescens, nov. gen. nov. spec, Neogeneia hortualis, nov. gen. nov. spec, and Kahliella simplex, (Horváth) Corliss and redefinition of the Kahliellidae (Ciliophora, Hypotrichida). Eur. J. Protistol. 31: 341-366

Foissner W. (1982) Ökologie and Taxonomie der Hypotrichida (Protozoa: Ciliophora) einiger österreichischer Böden. Arch. Protistenk. 126: 19-143

Foissner W. (1987) Soil protozoa: fundamental problems, ecological significance, adaptations in ciliates and testaceans, bioindicators, and guide to the literature. Progr. Protistol. 2: 69-212

Foissner W. (1998) An updated compilation of world soil ciliates (Protozoa, Ciliophora), with ecological notes, new records, and descriptions of new species. Eur. J. Protistol. 34: 195-235

Foissner W., Agatha S., Berger H. (2002) Soil ciliates (Protozoa, Ciliophora) from Namibia (Southwest Africa), with emphasis on two contrasting environments, the Etosha region and the Namib Desert. Part I. Text and line drawings. Part II: Photographs. Denisia 5: 1-1459

Gao F., Huang J., Zhao Y., Li L. F., Liu W., Miao M., Zhang Q., Li J., Yi Z., El-Serehy H. A., Warren A., Song W. B. (2017) Systematic studies on ciliates (Alveolata, Ciliophora): progress and achievements based on molecular information. Eur. J. Protistol. 61: 409-423

Gao F., Warren A., Zhang Q., Gong J., Miao M., Sun P., Xu D., Huang J., Yi Z., Song W. B. (2016) The all-data-based evolutionary hypothesis of ciliated protists with a revised classification of the phylum Ciliophora (Eukaryota, Alveolata). Sci. Rep. 6: 24874

$\mathrm{Hu}$ X., Kusuoka Y. (2015) Two oxytrichids from the ancient Lake Biwa, Japan, with notes on morphogenesis of Notohymena australis (ciliophora, sporadotrichida). Acta Protozool. 54: 107-122

Huang J., Luo X. T., Bourland W. A., Gao F., Gao S. (2016) Multigene-based phylogeny of the ciliate families Amphisiellidae and Trachelostylidae (Protozoa: Ciliophora: Hypotrichia). Mol. Phylogenet. Evol. 101: 101-110

Jankowski A. W. (2007) Phylum Ciliophora Doflein, 1901. In: Alimov, A. F. (ed.), Protista Part 2. Nauka, St. Petersburg, p. 415993

Jerome C. A., Simon E. M., Lynn D. H. (1996) Description of Tetrahymena empidokyrea $\mathrm{n}$. sp., a new species in the Tetrahymena pyriformis sibling species complex (Ciliophora, Oligohymenophorea), and an assessment of its phylogenetic position using small-subunit rRNA sequences. Can. J. Zool. 74: 1898-1906

Li F., Lyu Z., Li Y., Fan X., Al-Farraj S. A., Shao C., Berger H. (2017) Morphology, morphogenesis, and molecular phylogeny of Uroleptus (Caudiholosticha) stueberi (Foissner, 1987) comb. nov. (Ciliophora, Hypotricha), and reclassification of the remaining Caudiholosticha species. Eur. J. Protistol. 59: 82-98 
Li F., Xing Y., Li J., Al-Rasheid K. A. S., He S., Chen S. (2013) Morphology, morphogenesis and small subunit rRNA gene sequence of a soil hypotrichous ciliate, Perisincirra paucicirrata (Ciliophora, Kahliellidae), from the shoreline of the Yellow River, north China. J. Eukaryot. Microbiol. 60: 247-256

Li J., Chen X. M., Xu K. (2016) Morphology and small subunit rDNA phylogeny of two new marine urostylid ciliates, Caudiholosticha marina sp. nov. and Nothoholosticha flava sp. nov. (Ciliophora, Hypotrichia). J. Eukaryot. Microbiol. 63: 460-470

Liu W., Jiang J., Xu Y., Pan X., Qu Z, Luo X. T., Warren A., Ma H., Pan H. (2017) Great diversity in marine ciliates: fauna studies in China seas during the years 2011-2016. Eur. J. Protistol. 61: 424-438

Lu X.T., Huang J., Shao C., Al-Farraj S.A., Gao S. (2017) Morphology and morphogenesis of a novel saline soil hypotrichous ciliate, Gonostomum sinicum nov. spec. (Ciliophora, Hypotrichia, Gonostomatidae), including a report on the small subunit rDNA sequence. J. Eukaryot. Microbiol. 64: 632-646

Luo X. T., Fan Y., Hu X., Miao M., Al-Farraj S. A., Song W. B. (2016) Morphology, ontogeny, and molecular phylogeny of two freshwater species of Deviata (Ciliophora, Hypotrichia) from southern China. J. Eukaryot. Microbiol. 63: 771-785

Luo X. T., Gao F., Yi Z., Pan Y., Al-Farraj S. A., Warren A. (2017a) Taxonomy and molecular phylogeny of two new brackish hypotrichous ciliates, with the establishment of a new genus (Protozoa, Ciliophora). Zool. J. Linn. Soc. 179: 475-491

Luo X. T., Li L. F., Wang C., Bourland W. A., Lin X., Hu X. (2017b) Morphologic and phylogenetic studies of two hypotrichous ciliates, with notes on morphogenesis in Gastrostyla steinii Engelmann, 1862 (Ciliophora, Hypotrichia). Eur. J. Protistol. 60: $119-133$

Lv Z., Chen L., Chen L. Y., Shao C., Miao M., Warren A. (2013) Morphogenesis and molecular phylogeny of a new freshwater ciliate, Notohymena apoaustralis n. sp. (Ciliophora, Oxytrichidae). J. Eukaryot. Microbiol. 60: 455-466

Lv Z., Shao C., Yi Z., Warren A. (2015) A molecular phylogenetic investigation of Bakuella, Anteholosticha, and Caudiholosticha (Protista, Ciliophora, Hypotrichia) based on three-gene sequences. J. Eukaryot. Microbiol. 62: 391-399

Lynn D. H. (2008) The Ciliated Protozoa, Characterization, Classification, and Guide to the Literature, $3^{\text {rd }}$ edn., 380-387. Springer, Dordrecht.

Lynn D. H., Small E. B. (2002) Phylum Ciliophora Doflein, 1901. In: Lee JJ, Leedale GG, Bradbury PC, eds. The illustrated guide to the protozoa, 2nd edn. Lawrence: Allen Press Inc, 371-656 (year 2000)

Medlin L., Elwood H. J., Stickel S., Sogin M. L. (1988) The characterization of enzymatically amplified eukaryotic 16S-like rRNA-coding regions. Gene 71: 491-499

Miller M. A., Pfeiffer W., Schwartz T. (2010) Creating the CIPRES Science Gateway for inference of large phylogenetic trees. In Gateway Computing Environments Workshop (GCE), 14 Nov. New Orleans, LA: Institute of Electrical and Electronics Engineers, $1-8$.

Nylander J. (2004) MrModeltest v2. Program distributed by the author. Evolutionary Biology Centre, Uppsala University, 2.

Pan X., Bourland W. A., Song W. B. (2013) Protargol synthesis: an in-house protocol. J. Eukaryot. Microbiol. 60: 609-614

Pan X., Fan Y., Gao F., Qiu Z., Al-Farraj S. A., Warren A., Shao C. (2016) Morphology and systematics of two freshwater urostylid ciliates, with description of a new species (Protista, Ciliophora, Hypotrichia). Eur. J. Protistol. 52: 73-84
Paiva T. S., Borges B. N., Harada M. L., Silva-Neto I. D. (2009) Comparative phylogenetic study of Stichotrichia (Alveolata: Ciliophora: Spirotrichea) based on 18S-rDNA sequences. Genet. Mol. Res. 8: 223-246

Ronquist F., Huelsenbeck J. P. (2003) MrBayes 3: Bayesian phylogenetic inference under mixed models. Bioinformatics 19: 1572-1574

Shao C., Gao S., Hu X., Al-Rasheid K. A., Warren A. (2011) Ontogenesis and molecular phylogeny of a new marine urostylid ciliate, Anteholosticha petzi n. sp. (Ciliophora, Urostylida). J. Eukaryot. Microbiol. 58: 254-265

Shao C., Hu X., Warren A., Al-Rasheid K. A. S., Al-Quraishy S. A., Song W. B. (2007) Morphogenesis in the marine spirotrichous ciliate Apokeronopsis crassa (Claparède \& Lachmann, 1858) n. comb. (Ciliophora: Stichotrichia), with the establishment of a new genus, Apokeronopsis n. g., and redefinition of the genus Thigmokeronopsis. J. Eukaryot. Microbiol. 54: 392-401

Shao C., Li L. Q., Zhang Q., Song W. B., Berger H. (2014) Molecular phylogeny and ontogeny of a new ciliate genus, Paracladotricha salina n. g., n. sp. (Ciliophora, Hypotrichia). J. Eukaryot. Microbiol. 61: 371-380

Shao C., Lu X. T., Ma H. (2015) A general overview of the typical 18 frontal-ventral-transverse cirri Oxytrichidae $s$. l. genera (Ciliophora, Hypotrichia). J. Ocean. Univ. China. 14: 1-15

Shao C., Pan X., Jiang J., Ma H., Al-Rasheid K. A. S., Warren A., Lin X. (2013) A redescription of the oxytrichid Tetmemena pustulata (Müller, 1786) Eigner, 1999 and notes on morphogenesis in the marine urostylid Metaurostylopsis salina Lei et al., 2005 (Ciliophora, Hypotrichia). Eur. J. Protistol. 49: 272-282

Shimodaira H. (2002) An approximately unbiased test of phylogenetic tree selection. Syst. Biol. 51: 492-508

Shimodaira H., Hasegawa M. (2001) Consel: for assessing the confidence of phylogenetic tree selection. Bioinformatics 17: 1246-1247

Stamatakis A. (2014) RAxML version 8: a tool for phylogenetic analysis and post-analysis of large phylogenies. Bioinformatics 30: $1312-1313$

Swofford D. L. (2002) PAUP*: Phylogenetic analysis using parsimony (*and other methods). Version 4, Sunderland, MA

Tamura K., Peterson D., Peterson N., Stecher G., Nei M., Kumar S. (2011) MEGA5: molecular evolutionary genetics analysis using maximum likelihood, evolutionary distance, and maximum parsimony methods. Mol. Biol. Evol. 28: 2731-2739

Tuffrau M. (1979) Une nouvelle famille d'hypotriches, kahliellidae n. fam., et ses conséquences dans la répartition des stichotrichina. Trans. Amer. Micros. Soc. 98: 521-528

Tuffrau M. (1987) Proposition d'une classification nouvelle de I'Ordre Hypotrichida (Protozoa, Ciliophora), fondée sur quelques données récentes. Ann. Sci. Nat. Zool. 8: 111-117

Tuffrau M., Fleury A. (1994) Classe des Hypotrichea Stein, 1859. Traite. Zoologie. 2: 83-151

Wang J., Li L. F., Warren A., Shao C. (2017a) Morphogenesis and molecular phylogeny of the soil ciliate Rigidohymena quadrinucleata (Dragesco and Njine, 1971) Berger, 2011 (Ciliophora, Hypotricha, Oxytrichidae). Eur. J. Protistol. 60: 1-12

Wang J., Lyu Z., Warren A., Wang F., Shao C. (2016) Morphology, ontogeny and molecular phylogeny of a novel saline soil ciliate, Urosomoida paragiliformis n. sp. (Ciliophora, Hypotrichia). Eur. J. Protistol. 56: 79-89

Wang Y. Y., Chen X., Sheng Y., Liu Y., Gao S. (2017b) N6-adenine DNA methylation is associated with H2A.Z-containing well- 
122 Y. Ning et al.

-positioned nucleosomes in Pol II-transcribed genes in Tetrahymena. Nuc. Acid Res. 45: 11594-11606

Wilbert N. (1975) Eine verbesserte technik der protargolimprägnation für ciliaten. Mikrokosmos 64: 171-179

Yan Y., Fan Y., Chen X. R., Li L. F., Warren A., Al-Farraj S. A., Song W. B. (2016) Taxonomy and phylogeny of three heterotrich ciliates (Protozoa, Ciliophora), with description of a new Blepharisma species. Zool. J. Linn. Soc. 177: 320-334

Yan Y., Fan Y., Luo X. T., El-Serehy H. A., Bourland W. A., Chen X. R. (2018) New contribution to the species-rich genus Euplotes: morphology, ontogeny and systematic position of two species (Ciliophora; Euplotia). Eur. J. Protistol. 64: 20-39
Yi Z., Song W. B. (2011) Evolution of the order Urostylida (Protozoa, Ciliophora): new hypotheses based on multi-gene information and identification of localized incongruence. PLoS. One. 6: e17471

Zhao X. L., Wang Y. Y., Wang Y. R., Liu Y., Gao S. (2017) Tetrahymena histone methyltransferase TXR1 is required for both H3 and H3.3 lysine 27 methylation. Sci. Chin. Life Sci. 60: 264-270

Received on $27^{\text {th }}$ February, 2018; revised on $30^{\text {th }}$ May, 2018; accepted on $9^{\text {th }}$ July, 2018 